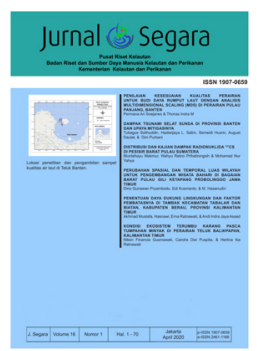

JURNAL SEGARA

http://ejournal-balitbang.kkp.go.id/index.php/segara

ISSN : 1907-0659

e-ISSN : 2461-1166

Nomor Akreditasi: 766/AU3/P2MI-LIPI/10/2016

\title{
DAMPAK TSUNAMI SELAT SUNDA DI PROVINSI BANTEN DAN UPAYA MITIGASINYA
}

\section{SUNDA STRAIT TSUNAMI IMPACT IN BANTEN PROVINCE AND ITS MITIGATION MEASURES}

\author{
Tubagus Solihuddin, Hadiwijaya L. Salim, Semeidi Husrin, August Daulat, \& Dini Purbani \\ Pusat Riset Kelautan \\ Badan Riset dan Sumberdaya Manusia Kelutan dan Perikanan, KKP \\ JI. Pasir Putih II Ancol Timur Lt. 4 Jakarta 14430
}

Diterima: 6 Maret 2020; Diterima Setelah Perbaikan: 5 Mei 2020; Disetujui Terbit: 15 Mei 2020

\begin{abstract}
ABSTRAK
Bencana tsunami Selat Sunda pada 22 Desember 2018 datang secara tiba-tiba tanpa ada peringatan dini dari pihak berwenang; merenggut nyawa lebih dari 430 orang dan menimbulkan kerusakan infrastruktur di wilayah pesisir. Penelitian ini bertujuan untuk melakukan penilaian cepat terkait dampak kerusakan dan mencoba melakukan analisis sumber tsunami serta memberikan rekomendasi terkait upaya pengurangan dampak risiko bencana tsunami di masa mendatang. Metode yang digunakan terdiri dari analisis citra satelit, observasi fisik lapangan, dan wawancara. Wilayah pesisir barat Kabupaten Pandeglang merupakan daerah yang terkena dampak tsunami paling parah, khususnya di Kecamatan Sumur, Panimbang, dan Labuan. Ketinggian gelombang tsunami di daerah tersebut mencapai 1-6 m dengan jangkauan genangan mencapai $200 \mathrm{~m}$ dari garis pantai. Sumber tsunami dari runtuhan material tebing G. Anak Krakatau akibat meningkatnya aktivitas vulkanik dan membangkitkan gelombang tsunami di sekitar Selat Sunda. Tingkat kesiapsiagaan masyarakat terhadap bencana dinilai masih rendah, oleh karena itu upaya mitigasi yang sangat direkomendasikan adalah adaptasi melalui peningkatan kewaspadaan dan pemahaman masyarakat terhadap bencana, juga penataan dan pengelolaan wilayah pesisir yang berwawasan bencana. Upaya tersebut dapat dikombinasikan dengan peningkatan kapasitas peringatan dini tsunami, pemetaan secara detil daerah rawan bencana, pengembangan desain rumah ramah tsunami.
\end{abstract}

Kata Kunci: Tsunami, Selat Sunda, Krakatau, Pandeglang, mitigasi.

\section{ABSTRACT}

The December 22, 2018 Sunda Strait tsunami disaster suddenly struck without any early warning from the authorities; claimed the casualties of more than 430 people and caused infrastructure damages in coastal areas. This study aims to conduct rapid assessments of the impact of tsunami and tries to analyze the source of tsunami as well as to provide recommendations to reduce the risk of tsunami in the future. The method used consists of satellite imagery analysis, on ground observation, and interviews. The west coast region of Pandeglang was most severely affected by the tsunami, especially in the Sumur, Panimbang, and Labuan district. The tsunami run-up reached 1-6 $\mathrm{m}$ high with a maximum inundation of $200 \mathrm{~m}$ from the coastline. The source of the tsunami from the flank collapsed of $\mathrm{G}$. Anak Krakatau due to increased volcanic activities generating tsunamis around the Sunda Strait. The preparedness of the communities towards disasters is still considered in low level. Therefore, the mitigation efforts that are highly recommended are adaptation through increasing public awareness and understanding of disasters as well as planning and managing disaster-persfective coastal areas. These efforts can be combined with the increasing of the capacity of tsunami early warning system, detailed mapping of disaster-vulnerability areas, development of tsunami-friendly house designs, etc.

Keywords: Tsunami, Sunda strait, Krakatau, Pandeglang, Mitigation.

Corresponding author:

Jl. Pasir Putih I Ancol Timur, Jakarta Utara 14430. Email: solihuddin@gmail.com. 


\section{PENDAHULUAN}

Sejarah mencatat bahwa pada tahun 1883 tsunami besar terjadi di Selat Sunda yang dipicu oleh letusan Gunung api Krakatau dan mengakibatkan kerusakan infrastruktur serta lebih dari 35.000 korban jiwa (Self \& Rampino, 1981; Simkin \& Fiske, 1983; Sigurdsson et al., 1991). Peristiwa yang sama kembali terjadi pada tahun 1928 dan memicu terjadinya tsunami kecil di sekitar G. Anak Krakatau (Yudhicara \& Budiono, 2008). Selain karena letusan gunung api, Selat Sunda juga memiliki potensi tsunami yang dipicu oleh proses tektonik atau gempa bumi akibat pergerakan lempeng di zona subduksi atau dikenal dengan istilah megathrust seperti tsunami yang terjadi di Aceh 2004, Mentawai 2005, dan Pangandaran 2006 (de Langeet et al., 2001; Maeno \& Imamura, 2007). Namun demikian, jejak tsunami akibat proses tektonik di Selat Sunda tersebut sampai hari ini belum ditemukan atau dibuktikan secara ilmiah (Prasetya, komunikasi personal, 5 Februari 2019).

Berbeda dengan tsunami sebelumnya, proses terjadinya tsunami Selat Sunda, 22 Desember 2018 disebabkan oleh runtuhan material G. Anak Krakatau yang muncul di atas permukaan laut Selat Sunda dengan ketinggian $338 \mathrm{~m}$ dan ketinggian setelah terjadinya erupsi adalah $110 \mathrm{~m}$ di atas permukaan laut (Kushendratno, 2019; Walter et al., 2019). Proses tersebut mirip dengan longsoran tebing G. Stromboli yang masuk ke dalam badan air dengan cepat dan memicu terjadinya gelombang tsunami setinggi $8 \mathrm{~m}$ pada 2002 di Italia (Maramai et al., 2005). Berdasarkan data dari Badan Nasional Penanggulangan Bencana (BNPB), tsunami Selat Sunda 22 Desember 2018, menghantam pesisir Provinsi Banten dan Lampung dengan korban jiwa lebih dari 430 orang, serta merusak infrastruktur, di mana kerusakan paling parah terjadi di Kabupaten Pandeglang, Provinsi Banten. Berdasarkan kondisi tersebut, wilayah pesisir barat Kabupaten Pandeglang yang berhadapan langsung dengan Selat Sunda menjadi sangat menarik untuk dilakukan kajian dan penilaian cepat terkait daerah terdampak tsunami baik secara fisik maupun sosial. Selain itu, evaluasi mengenai penggunaan lahan pesisir juga diperlukan sebagai bagian dari upaya pengurangan risiko bencana di kemudian hari.

Penelitian ini dilakukan di sepanjang pesisir barat Kabupaten Pandeglang yang berhadapan langsung dengan Selat Sunda (Gambar 1). Tujuan dari penelitian ini adalah untuk: 1) melakukan penilaian cepat daerah terdampak tsunami 22 Desember 2018 baik secara fisik maupun sosial, 2) mengetahui penyebab atau sumber tsunami, dan 3) memberikan rekomendasi pengurangan dampak risiko bencana. Informasi tersebut dapat digunakan Pemerintah Daerah setempat sebagai dasar pertimbangan dalam melakukan perencanaan, pengelolaan, dan penataan wilayah pesisir yang berwawasan bencana.

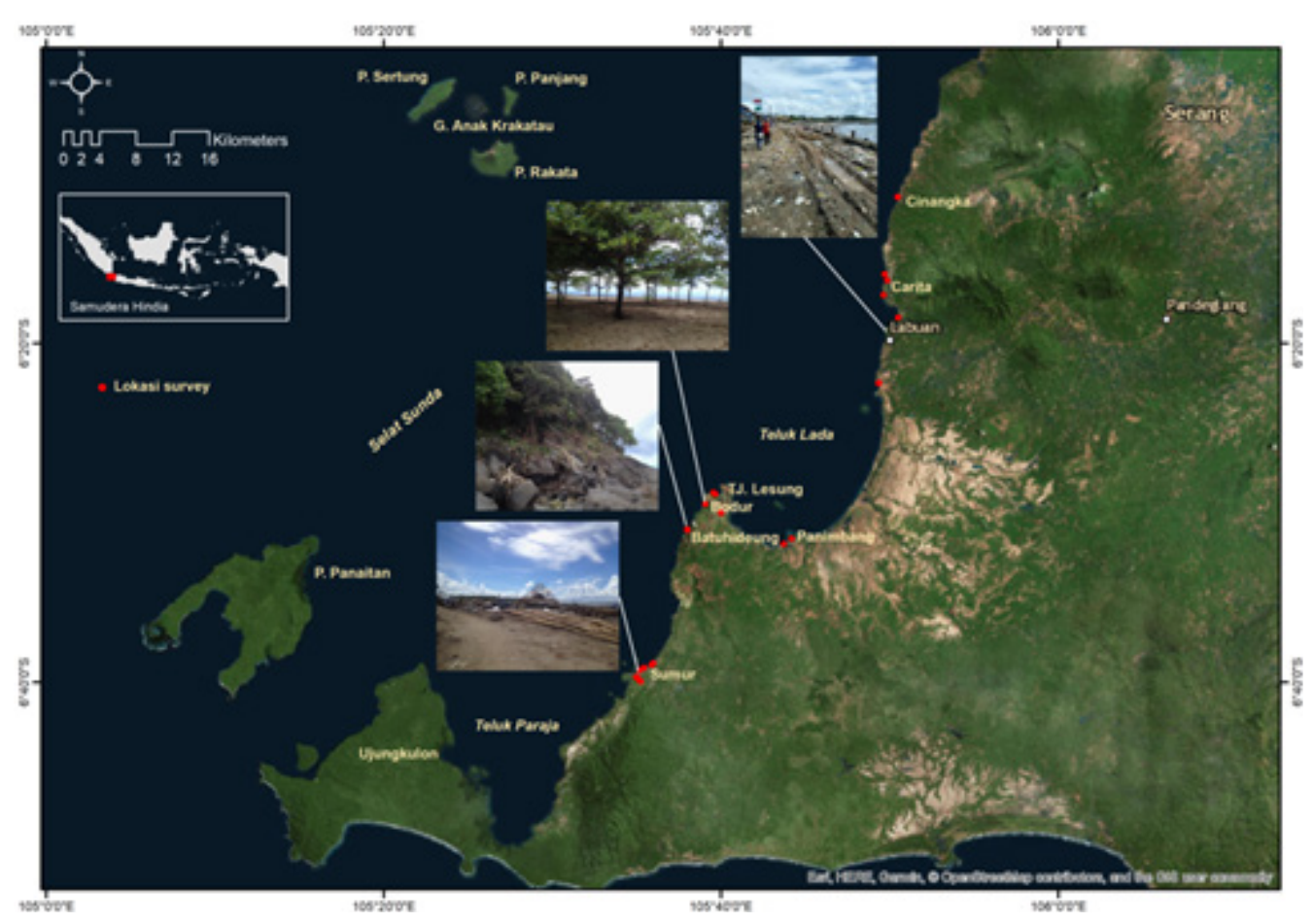

Gambar 1. Peta lokasi daerah penelitian di pesisir barat Kab. Pandeglang, Banten. (peta dasar adalah global imagery dari perangkat lunak ArcGis). 


\section{METODE PENELITIAN}

\section{Bahan dan peralatan}

Bahan yang digunakan dalam penelitian ini menggunakan citra satelit Sentinel-2A Level 1C dengan resolusi spasial 10 meter, yang merekam sebelum dan sesudah terjadinya tsunami 22 Desember 2018 yang dapat diunduh secara gratis dari https:// earthexplorer.usgs.gov/ (Tabel 1). Sistem proyeksi yang digunakan citra Sentinel-2A adalah Universal Tranverse Mercator (UTM) zona 48S dan datum World Geodetic System 1984 (WGS 1984). Daftar citra satelit Sentinel-2A yang digunakan dalam penelitian ini dapat dilihat dalam Tabel 1. Selain citra satelit, penelitian ini juga menggunakan peta administrasi kecamatan skala 1:1.000.000 tahun 2009 dari Badan Informasi Geospasial dan kuisioner sosial ekonomi untuk rumah tangga, kelembagaan sekolah, guru, dan murid. Sedangkan peralatan yang digunakan dalam pengamatan lapangan terdiri dari: i) GPS (Global Positioning System), untuk menentukan koordinat lokasi survei, ii) Levelling, untuk mengukur profil dan penampang pantai, dan iii) Hypsometer, untuk mengukur ketinggian run-up tsunami.

\section{Pemrosesan data citra satelit dan analisis daerah terdampak tsunami}

Pengolahan citra satelit terdiri dari beberapa tahapan yaitu: i) pra-pengolahan, ii) pengamatan lapangan, dan iii) klasifikasi berbasis objek. Prapengolahan terdiri dari proses penggabungan kanal yang digunakan terdiri dari kanal 2, 3, dan 4 (cahaya tampak), serta kanal 8 (inframerah dekat). Citra Sentinel-2A level 1C merupakan citra yang telah dilakukan koreksi radiometri dan geometrik. Citra yang sudah digabung kemudian dipotong (cropping) per kecamatan (Sumur, Panimbang, dan Labuan) menggunakan peta administrasi kecamatan dengan data garis pantai terbaru hasil digitasi. Masing-masing data citra sebelum dan sesudah tsunami kemudian dilakukan penajaman dengan teknik komposit kanal VNIR dan dilakukan klasifikasi tutupan lahan.

Klasifikasi tutupan lahan yang digunakan menggunakan metode klasifikasi berbasis objek dan penerapan algoritma nearest neighbor menggunakan perangkat lunak e-Cognition versi trial. Klasifikasi berbasis objek dikembangkan menggunakan sebuah pohon poses (process tree) yang terdiri dari beberapa tahapan, yaitu: i) segmentasi citra, yang menerapkan algoritma multi-resolution segmentation (MRS) dengan menggunakan parameter skala 50, ii) training area, yaitu proses identifikasi beberapa sampel kelas tutupan lahan yang telah diketahui pada area yang telah tersegmentasi, iii) penerapan algoritma nearest neighbor terhadap seluruh objek segmentasi, iv) exporting, untuk melakukan ekspor terhadap hasil klasifikasi dan selanjutnya disimpan dalam format shapefile (shp) untuk selanjutnya dilakukan editing menggunakan perangkat lunak Sistem Informasi Geografis (SIG). Proses editing dilakukan karena adanya kemungkinan terjadi kesalahan pengkelasan yang diakibatkan oleh skala segmentasi yang digunakan.

Hasil klasifikasi tutupan lahan selanjutnya diplot dan ditumpangsusunkan dengan peta elevasi berdasarkan data Digital Elevation Model (DEM) yang diperoleh dari website BIG (http://tides.big.go.id/ DEMNAS) untuk mengetahui luasan lahan terbangun pada ketinggian $0-10 \mathrm{~m}, 10,1-20 \mathrm{~m}, 20,1-30 \mathrm{~m},>30$ $\mathrm{m}$ sehingga diketahui daerah rawan terdampak genangan tsunami berdasarkan tinggi elevasinya.

\section{Observasi lapangan \\ Identifikasi fisik daerah terdampak}

Identifikasi fisik daerah terdampak meliputi pengamatan: 1) karakteristik pantai mencakup informasi geologi (resistensi batuan) dan relief (morfologi), 2) arah datang dan tinggi (run-up) gelombang tsunami, 3) maksimum jangkauan genangan tsunami (maximum inundation), dan 4) kerusakan yang ditimbulkan.

\section{Wawancara}

Wawancara dengan warga dilakukan secara purposive sampling di Kecamatan Labuan, Sumur, dan Panimbang dengan mengacu pada metode LIPIUNESCO/ISDR tahun 2006 dengan tujuan mengetahui tingkat kesiapsiagaan (preparedness) masyarakat menghadapi bencana alam, terutama gempa bumi dan tsunami dengan memperhitungkan lima indeks utama

Tabel 1.

Citra Sentinal-2A, sebelum dan setelah kejadian Tsunami Selat Sunda 2018

\begin{tabular}{llll}
\hline No & Citra Satelit Sentinel 2A & Lokasi & Waktu rekam \\
\hline 1 & L1C_T48MWT_A010039_20170525T031458 & Utara Pndeglang & 25-05-2017 \\
2 & L1C_T48MWT_A018476_20190105T030703 & Selatan Pandeglang & 05-01-2019 \\
3 & L1C_T48MWU_A017761_20181116T031814 & Utara Pandeglang & $16-11-2018$ \\
4 & L1C_T48MWU_A018476_20190105T030703 & Selatan Pandeglang & 05-01-.2019 \\
5 & L1C_T48MWU_A017761_20181116T031814 & G. Anak Krakatau & $11-11-2018$ \\
6 & L1C_T48MWU_A009968_20190202T032647 & G. Anak Krakatau & 02-02-2019 \\
\hline
\end{tabular}


Tabel 2. Kategorisasi kesiapsiagaan masyarakat menghadapi bencana (LIPI-UNESCO/ISDR, 2006)

\begin{tabular}{lll}
\hline No & Nilai indeks & Kategori \\
\hline 1 & $80-100$ & Sangat siap \\
2 & $65-79$ & Siap \\
3 & $55-64$ & Hampir siap \\
4 & $40-54$ & Kurang siap \\
5 & $<40(0-39)$ & Belum siap \\
\hline
\end{tabular}

sebagai indikator (Tabel 2): Pengetahuan dan sikap (KA), rencana darurat (EP), sistem peringatan (WS), kapasitas mobilisasi sumber (RMC), dan sistem kesiapsiagaan (PS). Semakin tinggi angka indeks berarti semakin tinggi pula tingkatan kesiapsiagaan dari subjek yang diteliti. Selanjutnya, tingkat kesiapsiagaan masyarakat dalam kajian ini dikategorikan menjadi lima (Tabel 2).

Kajian ini mengggunakan angka indeks gabungan tidak ditimbang, artinya semua pertanyaan dalam parameter tersebut mempunyai bobot yang sama. Penentuan nilai indeks untuk setiap parameter serta rincian perhitungan untuk mendapatkan nilai indeks berdasarkan data yang terkumpul dapat dilihat di LIPIUNESCO/ISDR (2006). Tabel 3 memperlihatkan jumlah responden yang terkumpul di empat kecamatan dengan empat kategori.

\section{HASIL DAN PEMBAHASAN}

\section{Dampak Tsunami}

Berdasarkan hasil analisis citra satelit Sentinel2A dengan kombinasi warna VNIR 832 (Gambar 2), diperoleh perbedaan rona (warna) citra yang agak mencolok di daerah pesisir antara sebelum dan sesudah tsunami, ditunjukkan dengan warna putih yang diinterpretasikan sebagai daerah terdampak tsunami atau jangkauan genangan tsunami Selat Sunda 22 Desember 2018 yang teridentifikasi di pesisir Kecamatan Labuan, Panimbang, dan Sumur.
Sedangkan berdasarkan hasil observasi fisik di lokasi terdampak, diperoleh informasi sebagai berikut:

1. Daerah yang terkena dampak tsunami paling parah adalah Kecamatan Sumur khususnya di Desa Kertamukti dan Kertajaya, Kecamatan Panimbang terutama di daerah Tanjung Lesung, dan Kecamatan Labuan terutama di Desa Teluk hingga Carita (Gambar 3).

2. Gelombang datang tsunami di Kecamatan Sumur umumnya dari arah barat dengan ketinggian mencapai $6 \mathrm{~m}$ dan jangkauan genangan hingga 200 m dari garis pantai, sedangkan di Kecamatan Panimbang umumnya dari arah baratdaya dengan ketinggian mencapai $6 \mathrm{~m}$ dan jangkauan genangan hingga $150 \mathrm{~m}$ dari garis pantai. Sementara, gelombang datang tsunami di Kecamatan Labuan umumnya dari arah baratdaya dengan ketinggian mencapai $3 \mathrm{~m}$ dan jangkauan genangan hingga $100 \mathrm{~m}$ dari garis pantai. Berdasarkan informasi dari warga, terdapat setidaknya 3 (tiga) gelombang tsunami dengan ketinggian gelombang pertama relatif rendah disusul dengan gelombang kedua dan ketiga yang lebih tinggi dan kuat (Gambar 3).

3. Pemanfaatan lahan pesisir di Desa Kertamukti dan Kertajaya Kecamatan Sumur adalah permukiman padat penduduk, pasar, sekolah, tempat ibadah, dan fasilitas kantor pemerintah, sedangkan di Tanjung Lesung Kecamatan Panimbang adalah kawasan pariwisata (hotel dan pantai wisata). Sementara di sepanjang Kecamatan Labuan dari Desa Teluk hingga Carita didominasi oleh pantai wisata, hotel, dan penginapan lainnya, disamping permukiman penduduk, dan pelabuhan.

4. Karakteristik pantai barat Kabupaten Pandeglang secara umum adalah pantai berpasir terdiri dari Endapan Aluvium (kerikil, pasir, dan lumpur) dan Endapan Undak Pantai (kerikil dan pasir rombakan batu gamping atau cangkang moluska). Terdapat juga pantai mangrove di Pantai Panimbang, pantai berbatu koral terumbu di sekitar Tanjung Lesung, dan pantai tebing berbatu di sekitar Batuhideung Panimbang (Gambar 4).

5. Morfologi pantai di Kecamatan Labuan secara umum memiliki relief rendah $(0-10 \mathrm{~m})$ hingga jarak

Tabel 3.

Jumlah responden di setiap kecamatan berdasarkan kategori Rumah Tangga, Kelembagaan, Guru, dan Murid Sekolah

\begin{tabular}{|c|c|c|c|c|c|c|c|c|c|c|c|c|c|c|}
\hline \multirow{2}{*}{$\begin{array}{l}\text { Responden } \\
\text { Kecamatan }\end{array}$} & \multicolumn{2}{|c|}{$\begin{array}{l}\text { Rumah } \\
\text { Tangga (RT) }\end{array}$} & \multicolumn{4}{|c|}{ Kelembagaan (S1) } & \multicolumn{4}{|c|}{ Guru (S2) } & \multicolumn{4}{|c|}{ Murid (S3) } \\
\hline & Pria & Wanita & TK & SD & SMP & SMA & TK & SD & SMP & SMA & TK & SD & SMP & SMA \\
\hline Labuan & 7 & 5 & - & - & - & - & - & - & - & - & - & - & - & - \\
\hline Panimbang & 3 & 2 & - & - & - & - & - & - & - & - & - & - & - & - \\
\hline Sumur & 3 & 2 & 11 & 1 & - & 6 & 11 & 1 & - & 8 & - & 4 & 1 & 5 \\
\hline
\end{tabular}



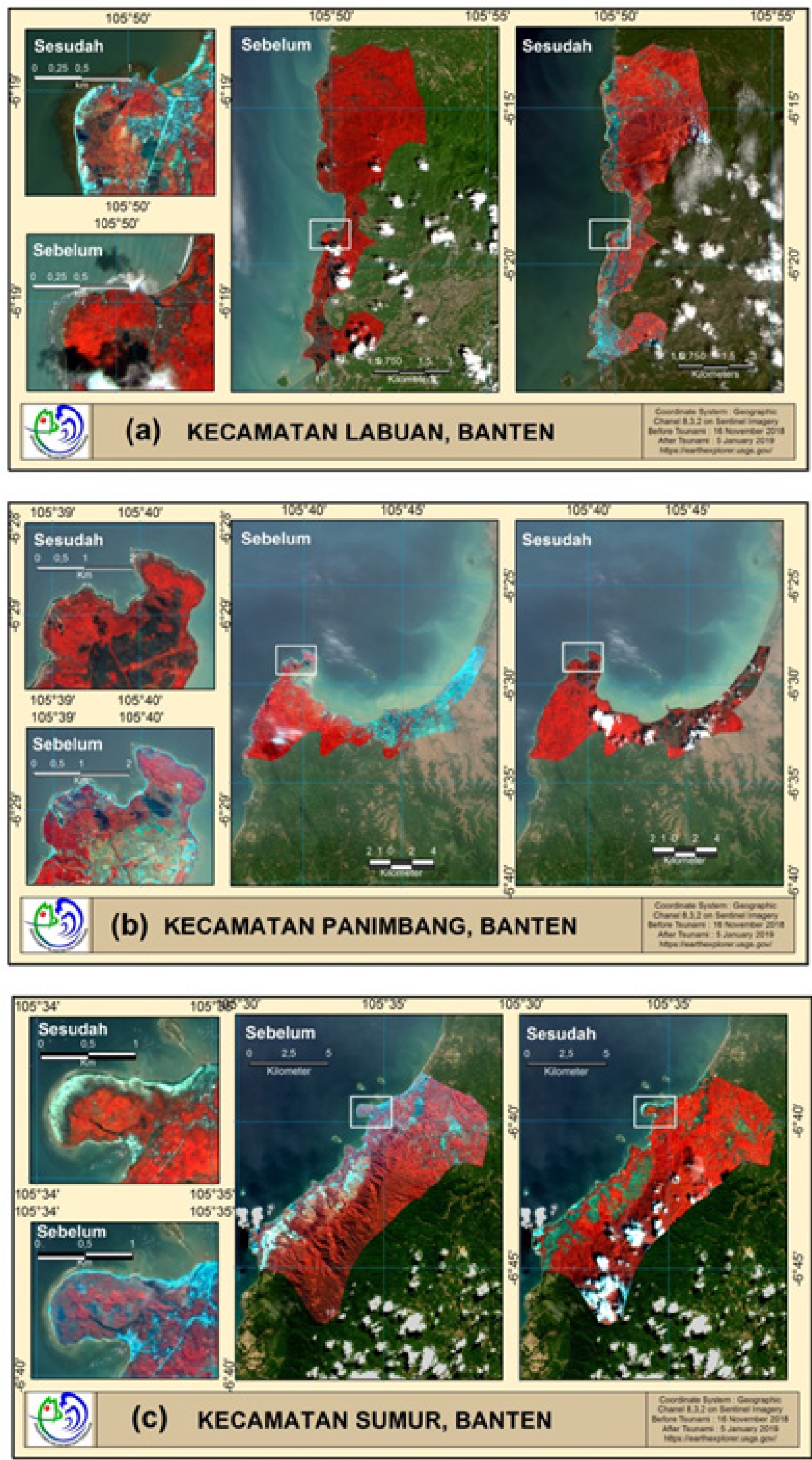

Gambar 2. Komposit kanal VNIR 832 citra satelit Sentinel-2 daerah pesisir a). Kecamatan Labuan, b) Kecamatan Panimbang, c). Kecamatan Sumur, menunjukan perubahan rona sebelum dan sesudah tsunami 22 Desember 2018 terjadi. 

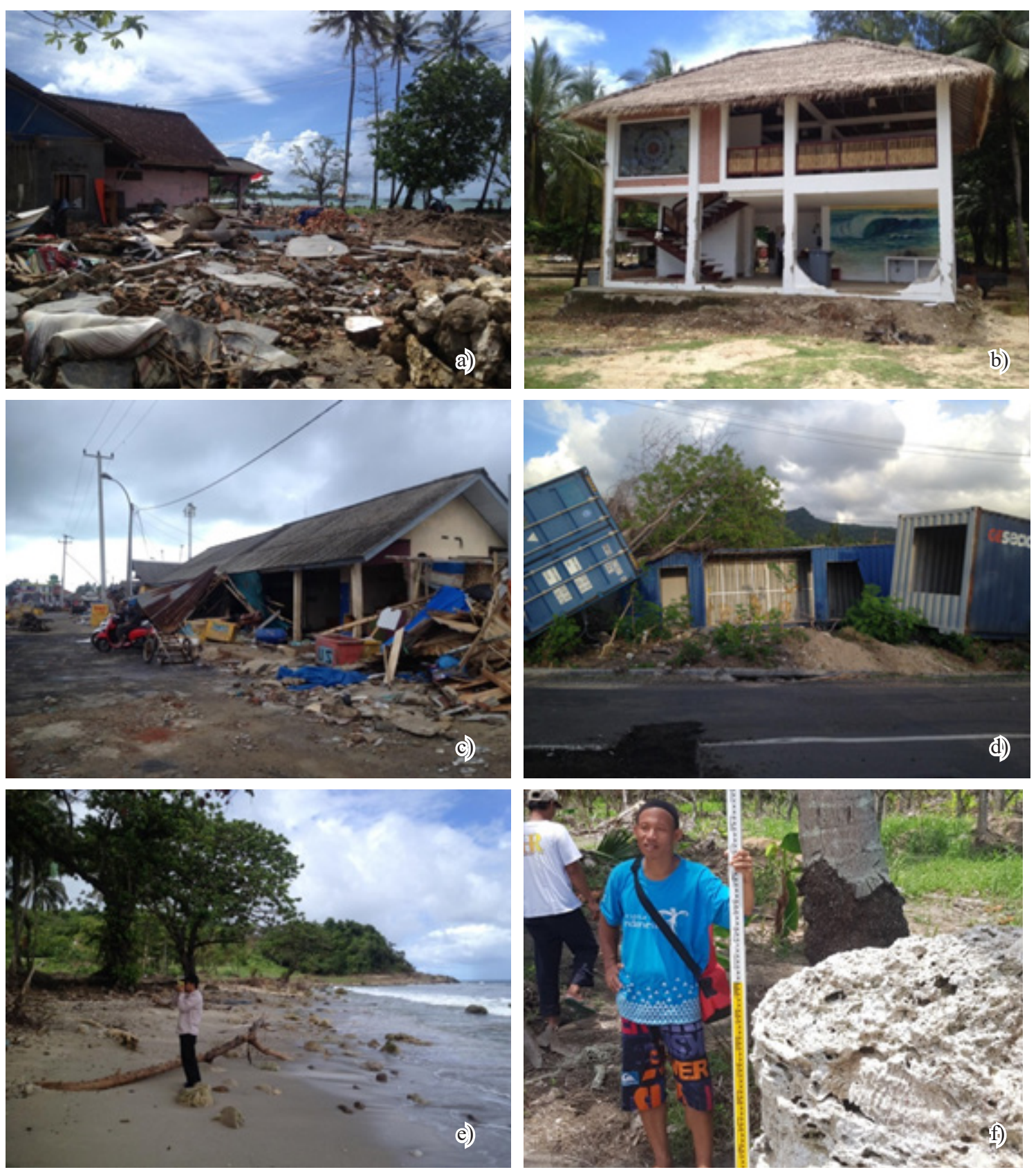

Gambar 3. a) Area permukiman padat penduduk di Desa Kertajaya, Sumur yang hancur disapu gelombang tsunami, b) Fasilitas pantai wisata yang hancur diterjang gelombang tsunami di kawasan Beach Club Tj. Lesung, c) Kawasan tempat pendaratan dan pelelangan ikan yang hancur di Desa Teluk, Labuan, d) Peti kemas yang digunakan sebagai tempat penginapan terseret hingga $50 \mathrm{~m}$ di Pantai Carita, e) Pengukuran jejak gelombang tsunami pada pohon menggunakan alat hypsometer, dan f) Pengukuran jarak dan tinggi jangkauan genangan gelombang tsunami menggunakan alat levelling.

$2 \mathrm{~km}$ dari garis pantai, sedangkan wilayah pesisir Kecamatan Panimbang memiliki relief rendah hingga sedang $(0-25 \mathrm{~m})$ pada jarak $0-2 \mathrm{~km}$ dari garis pantai, kecuali di daerah Batuhideung yang langsung dibatasi oleh tebing pada area kurang dari $100 \mathrm{~m}$ dari garis pantai. Sementara wilayah pesisir Kecamatan Sumur memiliki relief rendah hingga sedang $(0-25 \mathrm{~m})$ pada jarak $0-1,25 \mathrm{~km}$ dari garis pantai dan relief tinggi (>
$25 \mathrm{~m}$ ) berada pada jarak $1,25-2 \mathrm{~km}$ dari garis pantai (gambar 4).

Berdasarkan hasil analisis tutupan lahan citra satelit Sentinel-2A untuk lahan terbangun (permukiman, pasar, sekolah, kantor pemerintah, hotel, dan lainnya) yang ditumpangsusunkan dengan data DEM (Gambar 5), diperoleh informasi seperti terlihat dalam Tabel 4. 


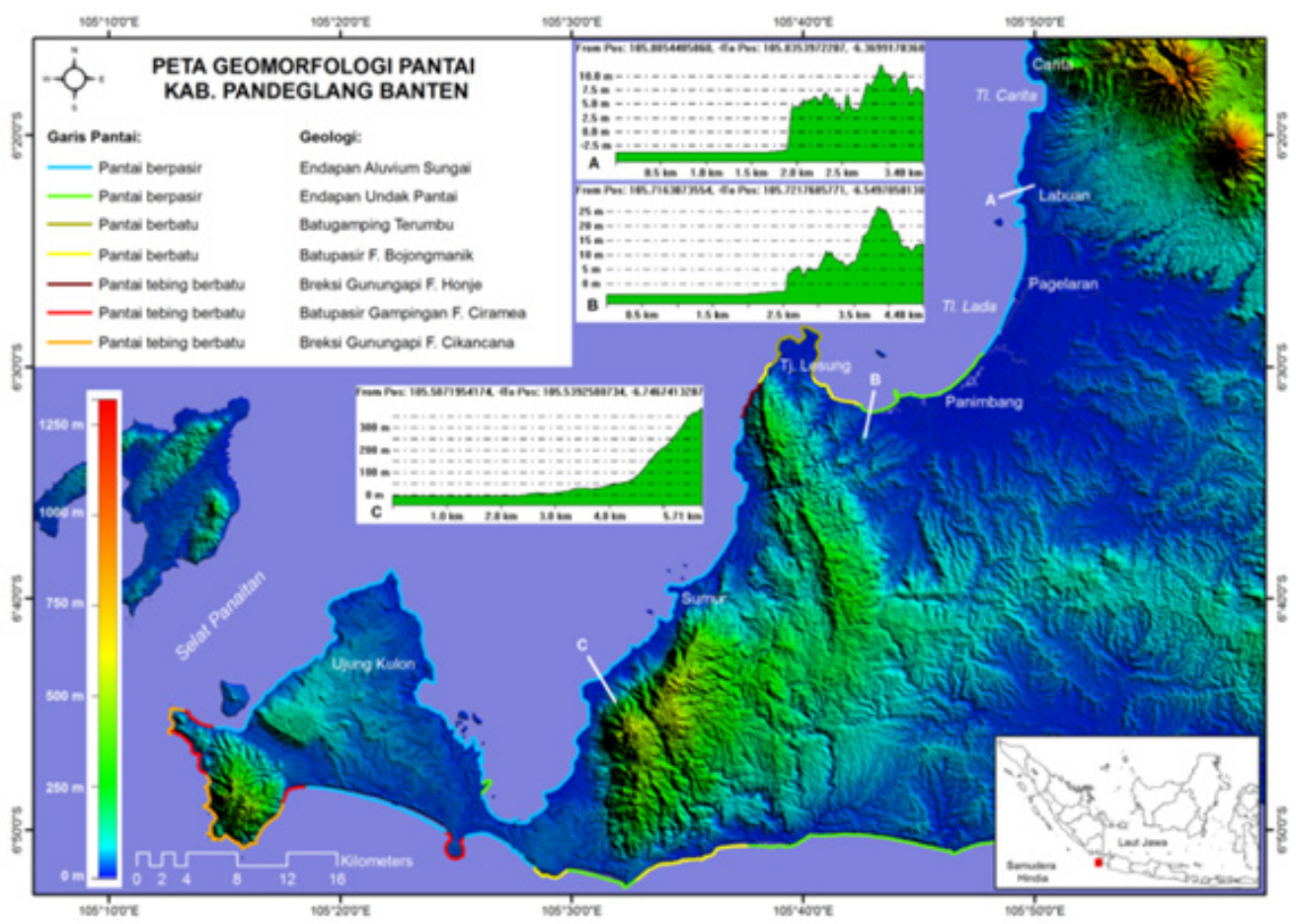

Gambar 4. Peta Geomorfologi pantai Kab. Pandeglang menunjukan karakteristik garis pantai, batuan penyusun, dan morfologi pesisir.

Berdasarkan hasil wawancara dengan 70 responden yang tersebar di Kecamatan Labuan, Panimbang, dan Sumur, diperoleh indeks kesiapsiagaan masyarakat sebagai berikut:

1. Kategori Rumah Tangga (RT) dengan nilai 33,3648 menunjukkan belum siap menghadapi bencana. Sebagian besar masyarakat menganggap bencana sebagai takdir Tuhan dan tidak mengetahui harus berbuat apa jika terjadi bencana dikarenakan tidak pernah ada sosialisasi tentang kebencanaan.

2. Kategori Kelembagaan Sekolah (S1) dengan nilai 25,5111 menunjukkan belum siap dalam menghadapi bencana. Sekolah tidak siap jika terjadi bencana baik dari kesiapan peralatan, pelatihan terhadap siswa, juga tidak adanya materi kebencanan dalam kurikulum pelajaran.

3. Kategori Guru (S2) dengan nilai 52,672 menunjukkan kurang siap dalam menghadapi bencana, artinya guru tidak paham akan terjadinya bencana sehingga tidak tahu harus berbuat apa.

4. Kategori Murid (S3) dengan nilai 55,940 menunjukkan hampir siap. Para siswa sudah sedikit paham akan bencana terutama murid SMA berdasarkan informasi yang mereka peroleh dari media seperti TV dan internet.

5. Indeks Total untuk komunitas sekolah berada pada posisi kurang siap dengan nilai indeks 43,781 .

\section{Asal-usul tsunami Selat Sunda 22 Desember 2018}

Berdasarkan hasil analisis citra satelit Sentinel2A G. Anak Krakatau sebelum dan setelah terjadinya tsunami Selat Sunda 22 Desember 2018 (Gambar 6a dan $6 b$ ), nampak terlihat jelas perbedaan morfologi G. Anak Krakatau yang mengindikasikan terjadinya longsoran tubuh G. Anak Krakatau ke arah baratdaya yang memicu terjadinya tsunami. Hal tersebut sesuai dengan hasil interpretasi visual dan aktivitas seismik letusan G. Anak Krakatau pada tanggal 22 Desember 2018 oleh Kushendratno (2019) dan Walter et al. (2019).

Tabel 4.

Analisis tutupan lahan untuk area terbangun

\begin{tabular}{|c|c|c|c|c|}
\hline \multirow[t]{2}{*}{ Kecamatan } & \multicolumn{4}{|c|}{ Luas Area (ha) berdasarkan Elevasi (m) dan presentasenya (\%) } \\
\hline & $0-10 \mathrm{~m}$ & $10,1-20 \mathrm{~m}$ & $20,1-30 \mathrm{~m}$ & $>30 \mathrm{~m}$ \\
\hline Labuan & $\begin{array}{l}390,08 \text { ha } \\
(53.33 \%)\end{array}$ & $\begin{array}{l}153,28 \text { ha } \\
(20,96 \%)\end{array}$ & $\begin{array}{l}48,28 \text { ha } \\
(6,6 \%)\end{array}$ & $\begin{array}{l}139,84 \text { ha } \\
(19,12 \%)\end{array}$ \\
\hline Panimbang & $\begin{array}{l}381,5 \text { ha } \\
(64,7 \%)\end{array}$ & $\begin{array}{l}140,84 \text { ha } \\
(23,89 \%)\end{array}$ & $\begin{array}{l}15,74 \text { ha } \\
(2,67 \%)\end{array}$ & $\begin{array}{l}51,54 \text { ha } \\
(8,742 \%)\end{array}$ \\
\hline Sumur & $\begin{array}{l}59,56 \text { ha } \\
(27,05 \%)\end{array}$ & $\begin{array}{l}100,29 \text { ha } \\
(45,54 \%)\end{array}$ & $\begin{array}{l}11,25 \text { ha } \\
(5,11 \%)\end{array}$ & $\begin{array}{l}49,11 \text { ha } \\
(22,3 \%)\end{array}$ \\
\hline
\end{tabular}



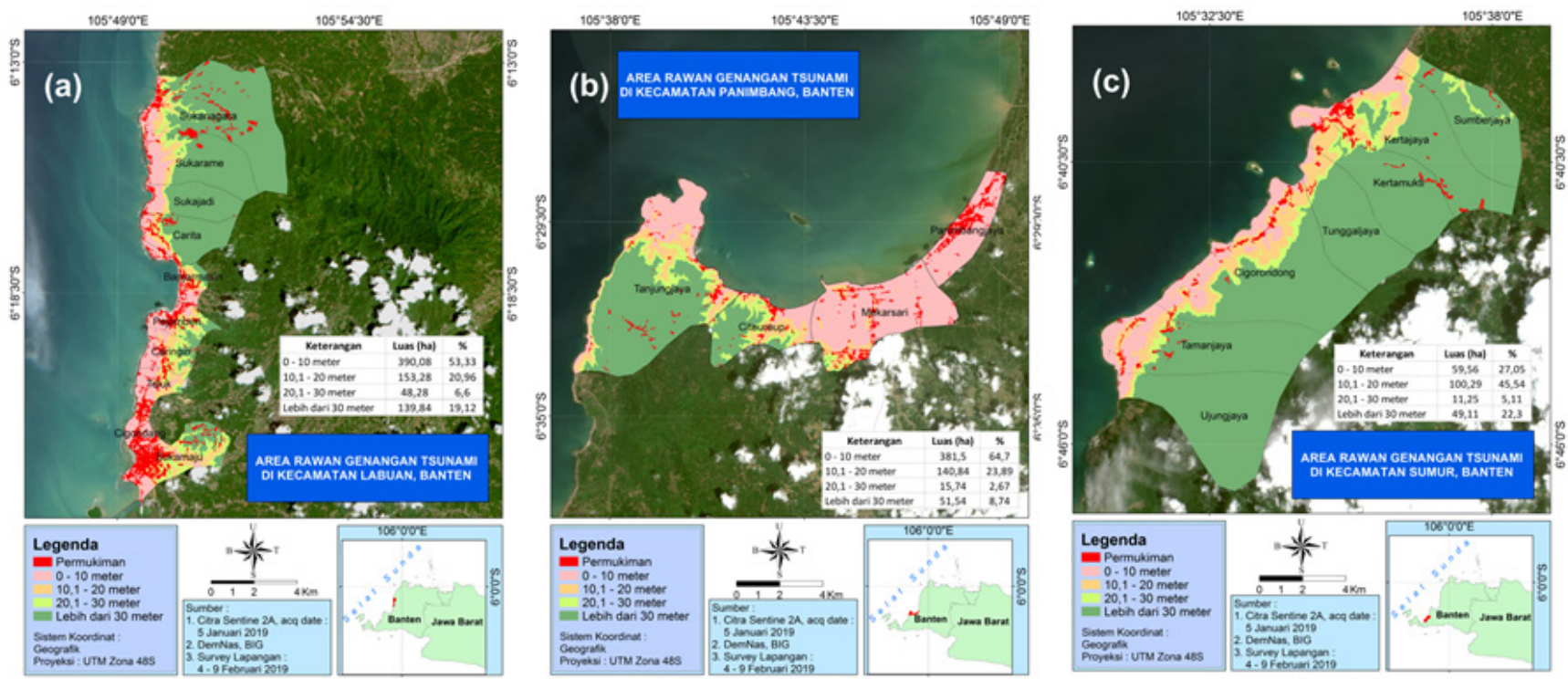

Gambar 5. Hasil analisis tutupan lahan citra satelit Sentinel-2 untuk daerah terbangun (warna merah) yang ditumpangsusunkan dengan data DEM daerah pesisir a). Kecamatan Labuan, b) Kecamatan Panimbang, dan c). Kecamatan Sumur, menunjukan luasan lahan terbangun pada ketinggian 0-10 m (warna merah muda), 10,1- $20 \mathrm{~m}$ (warna oranye), 20,1-30 m (warna hijau muda), dan $>30 \mathrm{~m}$ (warna hijau tua).

Selanjutnya, berdasarkan hasil pemodelan numerik sederhana yang dilakukan oleh tim (Gambar 7) terkait kejadian tsunami Selat Sunda 22 Desember 2018 menunjukkan Pulau Panaitan di pantai barat Pandeglang yang pertama kali terkena gelombang tsunami diikuti oleh Tanjung Lesung, Sumur dan Ujung Kulon. Energi tsunami berkurang secara signifikan di Teluk Lada Panimbang karena faktor topografi dasar laut yang relatif dangkal dibanding daerah lainnya. Kemudian gelombang tsunami menghantam Pantai Carita dan energinya semakin berkurang ke arah utara (Cinangka dan Anyer). Gelombang tsunami yang menghantam Provinsi Lampung di sisi timur Selat Sunda energinya tidak sebesar di Provinsi Banten.

Pulau Panaitan dan Ujung Kulon yang berada di bagian selatan diduga memantulkan kembali gelombang tsunami tersebut ke arah timur-timurlaut mengenai daerah pesisir Kecamatan Sumur, Panimbang, Labuan, Carita, hingga Anyer sehingga gelombang tsunami yang dirasakan masyarakat lebih dari 1 (satu) kali. Hasil interpretasi tersebut telah sesuai dengan berbagai hipotesis terkait tsunami Selat Sunda 22 Desember 2018 yang dipicu oleh longsoran material vulkanik ke laut (Deplus et al., 1995; Ghiacetti
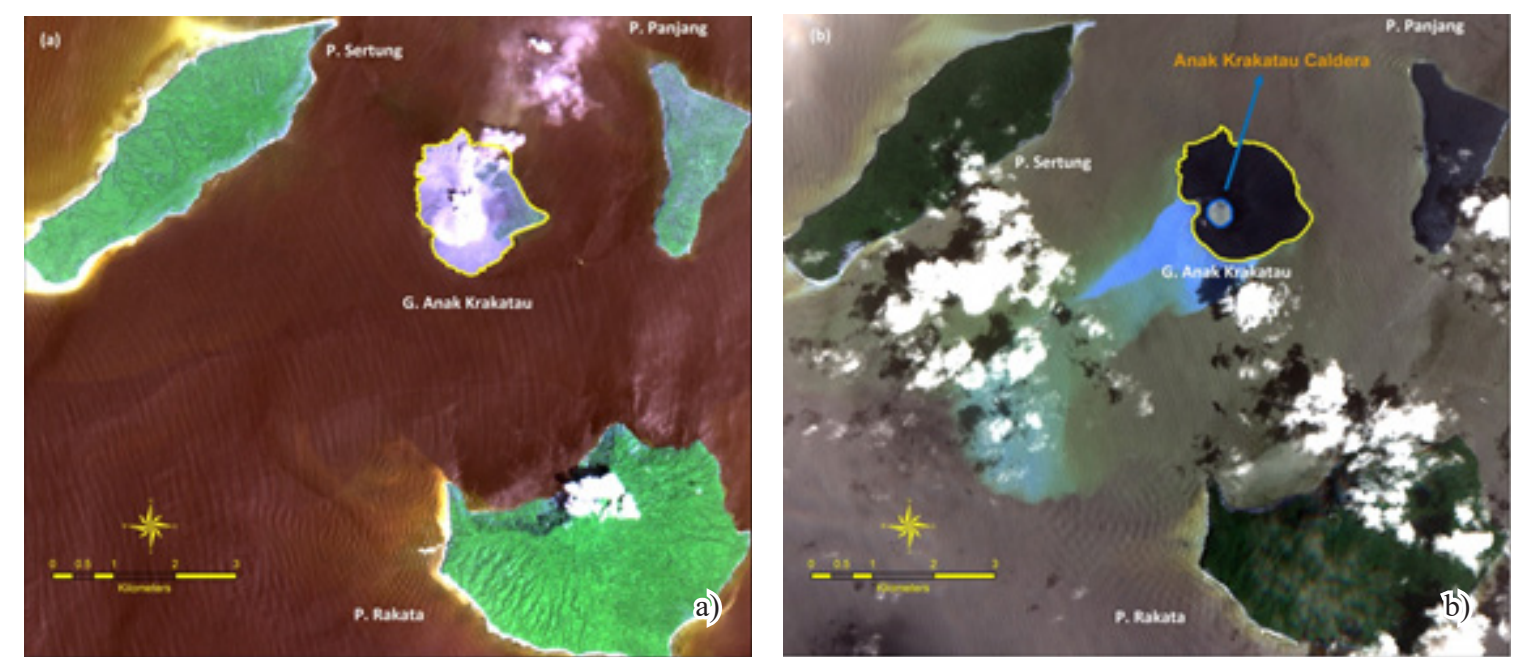

Gambar 6. Perbandingan morfologi G. Anak Krakatau berdasarkan citra satelit Sentinel-2A (a) sebelum dan (b) sesudah terjadinya tsunami (pengolahan data 2019). 
et al., 2012; Paris et al., 2012; Williams et al., 2019).

\section{Upaya mitigasi}

Tsunami yang dipicu oleh aktivitas gunung api dan longsoran material vulkanik seperti terjadi di Selat Sunda 22 Desember 2018 sangat jarang terjadi, sehingga harus menjadi pelajaran penting bagi masyarakat, Pemerintah Daerah setempat dan Pemerintah Pusat bahwa sumber bencana tsunami bukan hanya dari aktivitas tektonik seperti gempa bumi, namun juga dari aktivitas gunung api. Selain itu, berdasarkan hasil observasi lapangan dan penuturan saksi mata di lokasi terdampak bencana, maksimum jangkauan genangan tsunami mencapai $200 \mathrm{~m}$ dari garis pantai seperti terjadi di Desa Kertajaya Kecamatan Sumur, sehingga diperlukan perhatian khusus bagi pemerintah daerah dalam melakukan perencanaan dan penataan ruang pesisir pada radius 1-200 m dari garis pantai.

Upaya pengurangan dampak risiko bencana tsunami yang dilakukan harus secara menyeluruh tidak hanya aspek fisik semata, namun juga mempertimbangkan aspek sosial ekonomi, dan kelembagaan. Upaya mitigasi dari aspek fisik, harus memperhitungkan sumber atau pemicu tsunami, mengingat daerah Selat Sunda juga memiliki potensi tsunami yang dipicu oleh aktivitas tektonik dari zona subduksi di selatan Pulau Jawa (Yudhicara \& Budiono,
2008). Perlindungan pantai dengan menggunakan sabuk hijau (greenbelt) sangat direkomendasikan dalam upaya mengurangi dampak risiko bencana, mengingat sebagian besar karakteristik pantai barat Kab. Pandeglang tersusun oleh endapan aluvium dan undak pantai juga kondisi morfologi pesisirnya yang sebagian besar merupakan pedataran pantai dengan relief rendah (Gambar 4). Selain itu, sabuk hijau juga memiliki beberapa kelebihan diantaranya tersedia secara lokal, murah, ramah lingkungan, dan berkelanjutan. Jenis vegetasi yang umum digunakan adalah mangrove selain jenis vegetasi lainnya seperti beringin pantai, mahoni, ketapang, dan tanaman keras lainnya. Namun demikian, sabuk hijau juga memiliki beberapa keterbatasan diantaranya: 1) dapat tergerus erosi dengan cara cliffing (pengikisan vertikal), sheet wash (pengikisan lateral), dan tidal creek extension (perluasan area pasang-surut). 2) membutuhkan area kosong yang luas, dan 3) membutuhkan pasokan sedimen yang cukup.

Aspek sosial ekonomi mencakup kesiapsiagaan masyarakat terhadap bencana harus ditingkatkan melalui sosialisasi, edukasi, dan pelatihan. Berdasarkan hasil observasi dan wawancara dengan penduduk lokal di lokasi terdampak bencana (Gambar 8a dan $8 b$ ), upaya tersebut diatas belum maksimal dilakukan Pemerintah Daerah setempat. Bahkan, tsunami shelter (bangunan untuk perlindungan dan evakuasi korban

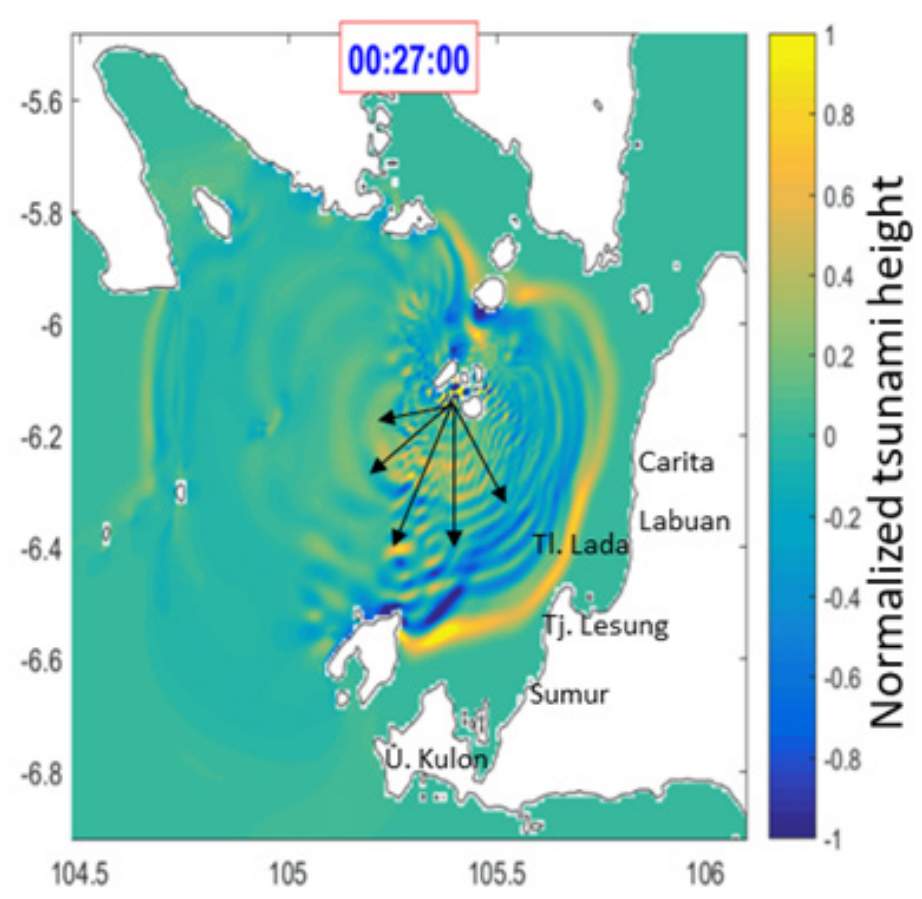

Gambar 7. Pemodelan numerik tsunami Selat Sunda 22 Desember 2018 menunjukkan Pulau Panaitan di pantai barat Pandeglang yang pertama kali terkena gelombang tsunami diikuti oleh $\mathrm{Tj}$. Lesung, Sumur, dan Ujung Kulon. Tanda panah menunjukkan arah dominan gelombang tsunami, sedangkan legenda ketinggian tsunami menunjukkan ketinggian yang dinormalisasi dengan rentang -1 hingga 1. 
tsunami) yang terdapat di Labuan belum berfungsi maksimal saat tsunami 22 Desember 2018 (Gambar 8c). Namun demikian, jalur evakuasi bencana sudah ada di beberapa lokasi walaupun belum cukup memadai, kurang terawat, dan masyarakat belum tersosialisasi secara maksimal terkait keberadaannya (Gambar 8d).

Upaya pengurangan dampak risiko bencana dengan alam. Masyarakat harus sadar betul bahwa bencana tidak dapat dihindari dan yang dapat dilakukan adalah mengurangi dampaknya. Menggali kearifan lokal dan membangun kesadaran kolektif masyarakat akan risiko bencana melalui kurikulum pendidikan di sekolah, sosialisasi, dan pelatihan merupakan opsiyang layak dipertimbangkan. Sistem peringatan dini tsunami dapat dipertimbangkan untuk diimplementasikan di kawasan pesisir Selat Sunda. Singkatnya jarak antara sumber tsunami dan kawasan pesisir terdampak ( 30 menit) harus menjadi pertimbangan utama dalam pemilihan sistem/teknologi peringatan dini tsunami. Selain itu, aspek biaya dan karakteristik masyarakat dalam merawat peralatan sistem peringatan dini juga perlu mendapat pertimbangan serius.

Berdasarkan pengamatan di lapangan, sistem peringatan dini tsunami di Labuan (dermaga TPI Teluk) telah terpasang sejak 2012 dengan memanfaatkan sistem pengukuran muka air laut yang dilengkapi dengan sirine (Gambar 9). Menurut penuturan warga, hingga tahun 2017, alat ini (sirine) masih berbunyi setiap tanggal 26 Desember. Namun, pada saat bencana tsunami terjadi di 2018, sistem ini sama sekali tidak berfungsi. Saat dikunjungi (Februari 2019), kondisi sensor sudah tidak berfungsi (rusak) dan tidak terkoneksi dengan sistem sirine. Sistem Pelampung Tsunami Lepas Pantai (offshore tsunami bouy Inabouy) juga pernah dipasang oleh BPPT pada tahun 2006. Namun alat ini juga telah lama dinyatakan mati/ hilang oleh BPPT dengan alasan utama vandalisme dan minimnya perawatan.

Sistem yang sama bantuan dari Jerman yang dipasang di Barat Sumatera sejak 2005 juga telah lama dinyatakan tidak berfungsi. Berkaca dari berbagai pengalaman tersebut, penggunaan teknologi sistem peringatan dini tsunami di Indonesia setidaknya harus mempertimbangkan dua aspek penting, yaitu: biaya yang tidak mahal (pemasangan dan perawatan) dan pencegahan terhadap aksi perusakan (vandalisme), selain aspek teknis seperti ketepatan mengukur dan kecepatan penyampaian peringatan dini. Rencana
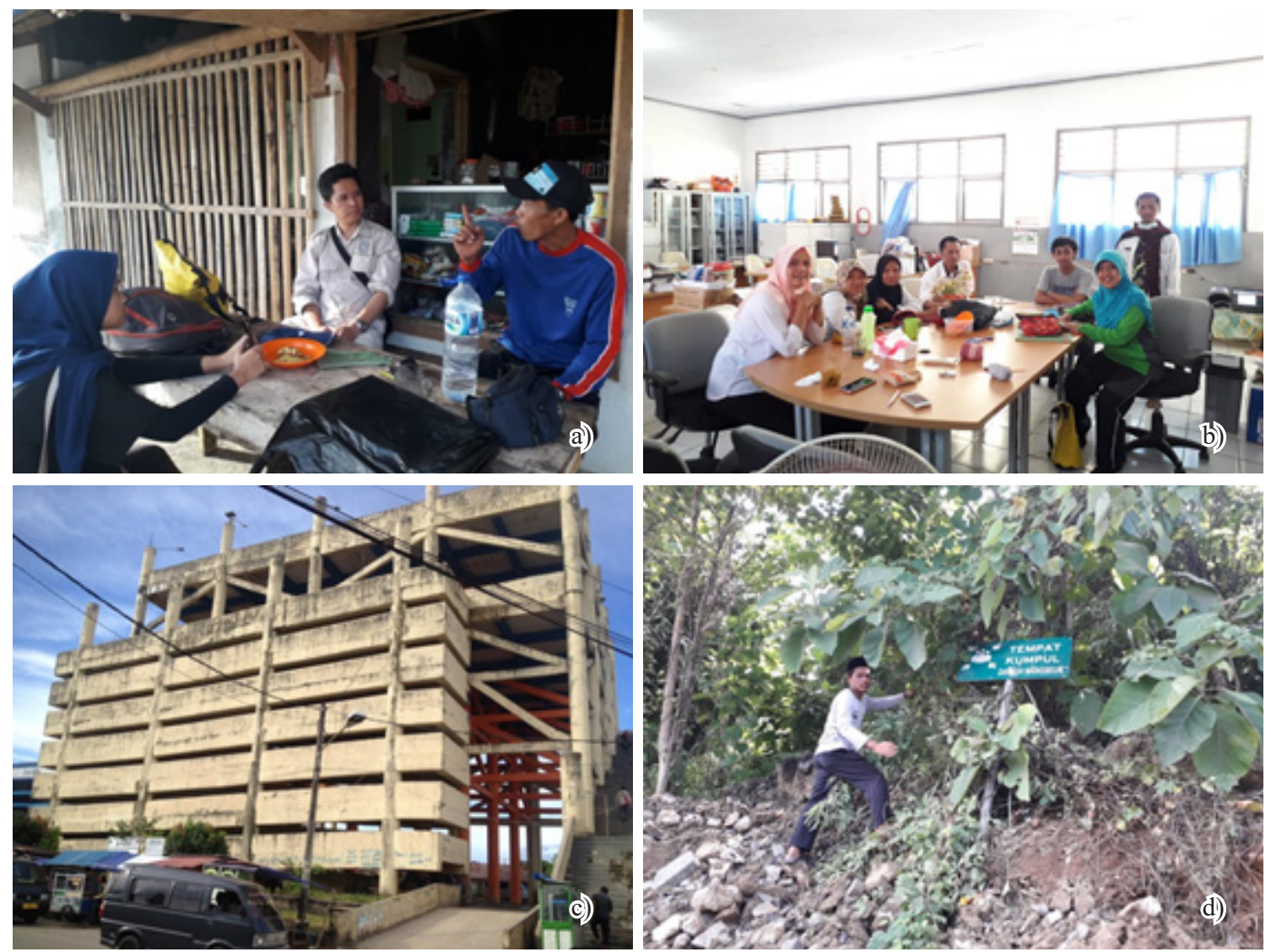

Gambar 8. a) Wawancara dengan Musa pegawai keamanan Pantai Lipo Carita, b) Wawancara dan penyebaran kuisioner di SMK 16 Sumur, c) Bangunan shelter (pelindung) tsunami yang terbengkalai di Labuan, dan d) Tanda jalur evakuasi tsunami di Kecamatan Sumur yang tidak terurus. 
BNPB untuk melibatkan unsur TNI dalam penjagaan fasilitas sistem peringatan dini bencana nasional (termasuk tsunami) perlu mendapat apresiasi. Rencana KKP bekerjasama dengan (Joint Research Centre-European Commision) JRC-EC, BMKG dan Ikatan Ahli Tsunami Indonesia (IATsI) untuk memasang sistem peringatan dini tsunami berbasis pengukuran anomali muka air berbiaya rendah (IDSL atau Inexpensive Device for Sea level measurement) juga perlu diapresisasi dan dibuktikan kehandalannya (Kompas, 2019).

Dari sisi kelembagaan, Pemerintah Daerah sesuai kewenangannya diatur dalam UU No. 24 Tahun 2007 tentang penanggulangan bencana memiliki peranan penting dalam melakukan koordinasi penanganan bencana baik sebelum, saat, maupun setelah terjadinya bencana. Sementara, Pemerintah Pusat melalui BNPB (Badan Nasional Penanggulangan Bencana) hanya bersifat mendukung, kecuali jika bencana tersebut dikategorikan sebagai bencana nasional yang menyebabkan kelumpuhan atau tidak berfungsinya pemerintahan di daerah. Dalam melakukan mitigasi atau pengurangan dampak risiko bencana, Pemerintah Daerah memiliki kewenangan melakukan penataan ruang pesisir yang berwawasan bencana. Sesuai dengan ketentuan Pasal 31 ayat (3) Undang-Undang Nomor 27 Tahun 2007 tentang Pengelolaan Wilayah Pesisir dan Pulau-Pulau Kecil sebagaimana telah diubah dengan Undang-Undang Nomor 1 Tahun 2014 dan selanjutnya telah diberlakukan Peraturan Presiden (Perpres) Nomor 51 Tahun 2016 tentang Batas Sempadan Pantai, yaitu daratan sepanjang tepian pantai, yang lebarnya proporsional dengan bentuk dan kondisi fisik pantai, minimal $100 \mathrm{~m}$ dari titik pasang tertinggi ke arah darat.

Menurut Perpres tersebut, Pemerintah Daerah Provinsi dan Kabupaten/Kota yang mempunyai sempadan pantai wajib menetapkan batas sempadan pantainya dalam Peraturan Daerah tentang Rencana Tata Ruang Wilayah (RTRW). Penetapan batas sempadan pantai ini dilakukan untuk melindungi dan menjaga: a. Kelestarian fungsi ekosistem dan segenap sumber daya di wilayah pesisir dan pulau-pulau kecil; b. Kehidupan masyarakat di wilayah pesisir dan wilayahwilayah kecil dari ancaman bencana alam; c. Alokasi ruang untuk akses publik melewati pantai; dan d. Alokasi ruang untuk saluran air dan limbah. Penataan ruang pesisir tersebut dapat disinergikan dengan mengadopsi peta tematik rawan bencana geologi dan bencana lainnya, pengembangan desain rumah tahan gempa, pengembangan desain teknologi peringatan dini tsunami, dan upaya mitigasi lainnya.

\section{KESIMPULAN}

Berdasarkan hasil penelitian dan pembahasan, maka dapat disimpulkan sebagai berikut:

1. Daerah terdampak tsunami 22 Desember 2018 berdasarkan penilaian secara fisik maupun sosial di Kab. Pandeglang adalah Kecamatan Sumur, Panimbang, dan Labuan.

2. Gelombang tsunami dibangkitkan oleh longsoran material vulkanik G. Anak Krakatau ke arah baratdaya, menghantam pulau-pulau di sekitarnya seperti P. Sertung dan P. Rakata, serta mempropagasi secara radial ke semua arah.

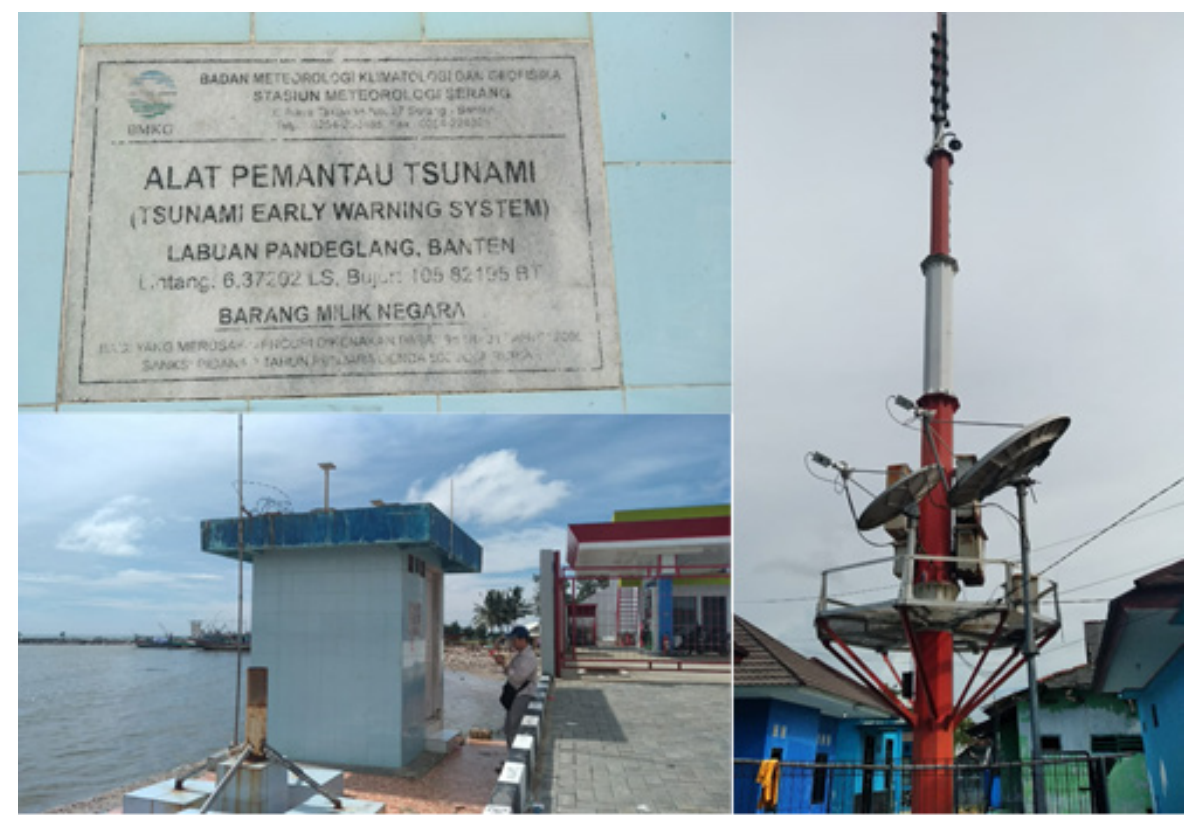

Gambar 9. Sistem peringatan dini tsunami berbasis pengukuran muka air laut di Labuan yang tidak berfungsi saat tsunami terjadi. 
3. Tanjung Lesung merupakan lokasi di Pantai Barat Pandeglang yang pertama kali terkena gelombang tsunami diikuti oleh Sumur dan Ujung Kulon. Kemudian gelombang tsunami menghantam Pantai Carita dan energinya berkurang ke arah utara (Cinangka dan Anyer).

4. Rekomendasi pengurangan dampak risiko bencana tsunami menggunakan sabuk hijau (greenbelt) dengan jenis vegetasi mangrove, beringin pantai, mahoni, ketapang, dan tanaman keras lainnya disesuaikan dengan kondisi pantai dan karakteristik lingkungan. Selain itu, diperlukan evaluasi perencanaan dan penataan ruang pesisir pada radius 1-100 $\mathrm{m}$ dari garis pantai oleh Pemerintah Daerah sesuai kewenangannya dalam UU maupun Perpres.

5. Sistem peringatan dini tsunami dapat dipasang di pesisir perairan Selat Sunda dengan mempertimbangkan aspek teknis (ketepatan dan kecepatan) dan aspek biaya murah (pemasangan dan perawatan) serta aspek keamanan dari aksi perusakan.

6. Tantangan penelitian selanjutnya adalah memvalidasi arah rambatan dan ketinggian gelombang tsunami 22 Desember 2018 berdasarkan hasil interpretasi dan observasi penelitian ini menggunakan pemodelan numerik.

7. Tingkat kesiapsiagaan warga, baik secara individu, rumah tangga, komunitas sekolah, guru dan siswa dirasakan masih sangat kurang sehingga memperparah dampak akibat bencana.

\section{PERSANTUNAN}

Penelitian ini dibiayai oleh DIPA Pusat Riset Kelautan Badan Riset dan Sumber Daya Manusia Kementerian Kelautan dan Perikanan 2019. Kami sangat berterima kasih kepada Bapak Riyanto Basuki (Kepala Pusat), Triyono (Kepala Bidang Mitigasi, Adaptasi, dan Konservasi), Hikmat Jayawiguna (Kepala Sub Bidang Mitigasi dan Adaptasi). Ucapan terima kasih juga kami sampaikan kepada seluruh pihak yang terlibat dalam penelitian ini khususnya kepada Dr. Eng. Rahman Hidayat (Kemenko Kemaritiman), Gegar Prasetya (Ikatan Ahli Tsunami Indonesia), Ardito Kodijat (IOTIC/IOC-UNESCO), Velly Asvaliantina (Kemenko Kemaritiman), Widjo Kongko (BPPT), dan Dinar Istiyanto (BPPT). Penulis pertama (Tubagus Solehudin) dalam artikel ini merupakan kontributor utama.

\section{DAFTAR PUSTAKA}

Anonim. (2019). https://earthexplorer.usgs.gov/diakses, diakses pada 07 Januari 2019.

Anonim. (2019). http://tides.big.go.id/DEMNAS, diakses pada 20 Januari 2019. de Lange, W.P., Prasetya, G.S., \& Healy, T.R. (2001). Modelling of tsunamis generated by pyroclastic flows (ignimbrites). Natural Hazards, 24, 251-266.

Deplus, C., Bonvalot, S., Dahrin, D., Diament, M., Harjono, H., \& Dubois, J. (1995). Inner structure of the Krakatoa volcanic complex (Indonesia) from gravity and bathymetry data. Journal of Volcanology and Geothermal Research, 64, 2351.

Giachetti, T., Paris, R., Kelfoun, K., \& Ontowirjo, B. (2012). Tsunami hazard related to a flank collapse of Anak Krakatau Volcano, Sunda Strait, Indonesia. Geological Society, London, Special Publications, 361, 79-90. doi: 10.1144/SP361.7.

Kompas. (2019). Generasi baru pemantau tsunami dipasang, Kompas cetak edisi Kamis, 31 Januari 2019.

Kushendratno. (2019). Pemantauan Visual Letusan Gunung Anak Krakatau Periode Juli-Desember 2018. Badan Geologi Press, Bandung, Hal 277 296.

LIPI - UNESCO/ISDR. (2006). Kajian Kesiapsiagaan Masyarakat Dalam Menghadapi Bencana Gempa Bumi dan Tsunami. 579 hal, LIPI-UNESCO/ISDR, Jakarta.

Maeno, F. \& Imamura, F. (2007). Numerical investigations of tsunamis generated by pyroclastic flows from the Kikai caldera, Japan. Geophysical Research Letters, 34(23), 1-5, doi: 10.1029/2007GL031222.

Maramaia, A., Graziania, L., Alessiob, G., Burratoa, P., Colinia, L., Cuccia, L., Nappib, R., Nardia, A., \& Vilardob, G. (2005). Near- and farfield survey report of the 30 December 2002 Stromboli (Southern Italy) tsunami. Marine Geology, 215(12), 93-106.

Paris, R., Switzer, D.A., Belousova, M., Belousov, A., Ontowirjo, B., Whelley, L.P., \& Ulvrova, M. (2012). Volcanic tsunami: a review of source mechanisms, past events and hazards in Southeast Asia (Indonesia, Philippines, Papua New Guinea). Nat Hazards (2014), 70, 447-470. DOI 10.1007/ s11069-013-0822-8.

Prasetya, G. (2019). Endapan tsunami yang diakibatkan oleh proses tektonik megathrust di Selat Sunda belum ditemukan atau dibuktikan secara ilmiah. Komunikasi personal, 5 Februari 2019.

Self \& Rampino. (1981). The 1883 eruption of Krakatau. 
Nature, 294, 699-704.

Sigurdsson, H., Carey, S. \& Mandeville, C. (1991). Submarine pyroclastic flows of the 1883 eruption of the Krakatau Volcano. National Geographic Research and Exploration, 7, 310-327.

Simkin, T. \& Fiske, R.S. (1983). Krakatau 1883: The Volcanic Eruption and its Effects. Smithsonian Institution Press, Washington, DC. Stehn, C. E. 1929. The geology and volcanism of the Krakatau Group. In: Proceedings of the Fourth Pacific Science Congress, Batavia-Bandoeng (Java), May-June, 1929.

Walter, T.R., Haghshenas Haghighi, M., Schneider, F.M., Coppola, D., Motagh, M., Saul, J., \& Gaebler, P. (2019). Complex hazard cascade culminating in the Anak Krakatau sector collapse. Nature Communications, 10(1), 1-11. https://doi. org/10.1038/s41467-019-12284-5.

Williams R., Rowley P., \& Garthwaite M.C. (2019). Reconstructing the Anak Krakatau flank collapse that caused the December 2018 Indonesian Tsunami. Geology, 47(10), 973-976.

Yudhicara. \& Budiono, K. (2018). Tsunamigenik di Sekat Sunda: Kajian terhadap Katalog Tsunami Soloviev. Jurnal geologi Indonesia, 3(4), 241-251 
Dampak Tsunami Selat Sunda ...... dan Upaya Mitigasinya (Solihudin, ST, et al.) 